Review Article

www.ijrap.net

\title{
CUSCUTA REFLEXA (DODDER PLANT): A CRITICAL REVIEW ON THE MEDICINAL PLANT USED IN AYURVEDA
}

Lalchand ${ }^{1}$, Sahu Rekha ${ }^{2}$, Gupta Rakshpal ${ }^{3}$, Rout Om Prakash ${ }^{4 *}$

${ }^{1}$ M.D. Scholar, Post Graduate Department of Dravyaguna, Govt. Ayurved College, Raipur, Chhattisgarh, India

${ }^{2}$ M.D. Scholar, Post Graduate Department of Dravyaguna, Govt. Ayurved College, Raipur, Chhattisgarh, India

${ }^{3}$ Professor \& HOD, Post Graduate Department of Dravyaguna, Govt. Ayurved College, Raipur, Chhattisgarh, India

${ }^{4}$ Lecturer, Post Graduate Department of Dravyaguna, Govt. Ayurved College, Raipur, Chhattisgarh, India

Received on: 28/08/17 Accepted on: 03/10/17

\author{
*Corresponding author \\ E-mail: omprakashrout2000@gmail.com
}

DOI: 10.7897/2277-4343.086288

\begin{abstract}
Cuscuta reflexa is a parasitic plant which belongs to family Convolvulaceae. It is commonly known as dodder plant, amarbel, akashabela. Traditionally it is called miracle plant. It is rootless, perennial, leafless climbing parasitic twining herb which takes food from host plant with help of special organ called haustorium. This review article will collect the detailed description of synonyms, vernacular name, habitat, botanical description, ethno-medicinal uses, properties, chemical constituents, pharmacological uses of Cuscuta reflexa from different classical Ayurvedic literature as well as modern research journals. This review article deals with Antihypertensive, Antidiabetic, Antioxidant, Hair growth promoting, Antimicrobial, Spasmolytic, Antitumor, Anti-arthritic, Nephroprotective, Antiviral, Anti-inflammatory, Antipyretic effect of Cuscuta reflexa. More researches should be done in this plant to explore its mode of action and uses.
\end{abstract}

Keywords: Cuscuta, Amarbel, Ayurveda, Ethnomedicine.

\section{INTRODUCTION}

Medicinal plants have been used since ages in traditional medicines due to their therapeutic potential and the search in medicinal plants have led to the discovery of novel drug candidates used against various diseases ${ }^{1}$. Cuscuta reflexa is commonly called as dodder plant, and also known as devil's hair, witch's hair, love vine, amarbel or akashabela etc. Cuscuta reflexa is a parasitic weed plant and also an extensive climber. It grows as homoparasite ${ }^{2}$.Cuscuta reflexa is rootless, leafless, perennial parasitic twining herb of Convolvulaceae family, commonly known as amarbel or dodder. It has no chlorophyll and cannot make its own food by photosynthesis. Dodder plant has the ability not only to recognize its host plant but also to move towards its prey with significant precision and efficiency. Dodder plant can also choose an appropriate host between many plants on the basis of volatile compounds release by the host plant as their normal process of transpiration ${ }^{3}$. It spread from one host plant to another, and on each victim, they twin and cling tightly with special branching organs called haustorium. Haustorium penetrates the host and connect to the host xylem as well as to the host phloem and absorb from it both water and elaborated food stuff such as sugar and amino acids ${ }^{4}$. It is believed that the parasitic herbs extract healthy and potential sap from the host plant and if their host plants are medicinal plants then these parasitic herbs show many similar properties to host plants. Cuscuta species feeding on commonly used medicinal herbs are given special attention by traditional healers. It lives its entire life without attachment to the ground and grows with the help of seeds which are minute and produced in large quantities. Seeds have a large coating and survive in the soil for 5-10 years ${ }^{5}$.

Stems very long, rather stout, closely twining, branched, glabrous, pale greenish yellow, sometimes dotted with red. Flowers solitary or in umbellate clusters of 2-4 or in short racemes; pedicels short, glabrous, usually curved (rarely 0); bracts $1.5 \mathrm{~mm}$. long, ovate-oblong, obtuse fleshy. Calyx divided almost to the base; lobes $3 \mathrm{~mm}$. long, slightly unequal, broadly ovate, obtuse, glabrous and fleshy. Corolla white; tube $6-8$ by 4 $\mathrm{mm}$., almost cylindrical; lobes 2.5-3 mm. long, deltoid, acute, reflexed; scales almost at the base of the corolla -tube, large, oblong, subquadrate or somewhat obovate, fimbriate and incurved at the apex. Stamens in the throat of the corolla- tube; filaments scarcely any; anthers about $1 / 2$ - exerted beyond the top of the corolla-tube. Ovary ovoid; style simple, very short and thick; stigmas 2, distinct, large thick and fleshy, $1.5 \mathrm{~mm}$. long, ovoid. Capsules 6-8 mm. diam., depressed-globose, glabrous, circumscissile near the base. Seeds 2-4, large, black, glabrous ${ }^{3}$.Cuscuta reflexa is investigated for Antihypertensive, Antidiabetic, Antioxidant, Hair growth promoting, Antimicrobial, Spasmolytic, Antitumor, Antiviral, Antiinflammatory, Antipyretic effect.

\section{IN AYURVEDIC LITERATURE}

Cuscuta reflexa has no any reference in Vedic and Samhita Kala. It is mentioned in following Nighantus

\section{Bhavprakash Nighantu}

In BhavprakashNighantu synonyms akashavalli, amarvallari, khavalliare described. It is It is tikta (bitter) and kashaya (astringent), malasangrhahak (stool binder), pichchhil (sticky), netraroganashak (eye disorders), jathragnivardhak (appetizer), hridya(cardiotonic) and destroys the pitta (bile), kapha(cough) and aamnashak(undigested food) ${ }^{6}$.

\section{Raj Nighantu}

The synonyms akashvalli, khavalli, asprsha, vyomvallika are mentioned. The synonym of Akash(Sky) co joint with valli (climber) word makes the synonym "akashavalli". Akashvalli 
has madhurrasa(sweet taste). It is pittashamak (cholagogue), rasayana(rejuvenator), balavardhak (strengthen body) and has the properties of divyaausadhies(Divine power). ${ }^{7}$

\section{Nighantu Adarsh}

The plant is distributed with the name of aakashbel and amarbel. It is found on some trees as parasite and mentioned under karpurtwakadivarga. It is balya (strengthen body), keshya (hair strengthening), vranropan (wound healer) and vrishya (aphrodisiac) $^{8}$.

\section{Shankar Nighantu}

The synonyms are akasvalli, amerbel, akashbel and aaloklata. Its taste is bitter, yellow colored with white flower. The dose is 1 to12 masa. The properties are pichchhil (sticky), netrarognashak (eye disorders), jathragni vardhak (appetizer) and hridya (cardiotonic). It spreads over Ber and Aadu trees. It is a rootless climber so it is called as Akashbel ${ }^{9}$.

\section{Madanpal Nighantu}

It is mentioned under Abhayaadivarga. Synonyms are akashvalli, amarvallariand amarbel. It has grahini (astringent), tikshna (penetrating), and pichchhil (sticky)- rog nashakproperty ${ }^{10}$.

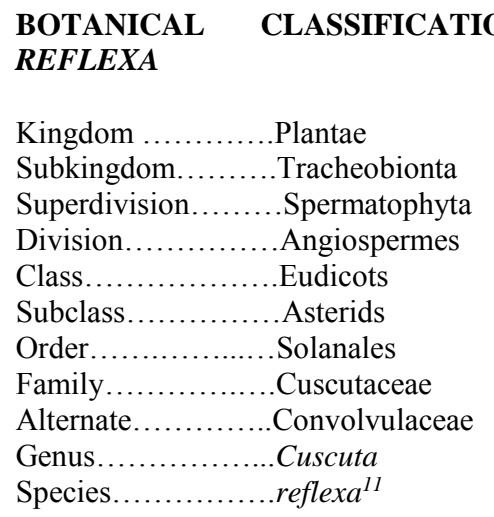

\section{SYNONYMS}

akashavalli, amarvallari, khavalli, asprsha, vyomvallika, aakashbel, amarbel, aaloklata.

\section{VERNACULAR NAMES}

$\begin{array}{ll}\text { Hindi } & \text { Amarbel } \\ \text { Bengali }- & \text { Swarnlata } \\ \text { Malyali }- & \text { Nirmuli } \\ \text { Gujrati - } & \text { Akasbel } \\ \text { Telugu - } & \text { Nulutega } \\ \text { Tamil - } & \text { Erumaikkottan } \\ \text { Persian - } & \text { Aftimoon } \\ \text { Assamese- } & \text { Akakhilata } \\ \text { English - } & \text { Dodder }^{12}\end{array}$

\section{HABITAT}

This parasitic plant climbs over the trees and shrubs. Cuscuta is found in the temperate and tropical regions of the world with huge species diversity in tropical and subtropical regions. It is found throughout about 6 species are found abundant in Bengal plains ${ }^{13}$.It is usually found in India and Ceylon up to an altitude of $2348 \mathrm{~m}$. It is also found in Afghanistan, Malaysia, Nepal and Thailand. It grows on thorny, non thorny and other shrubs, sometimes completely covering bushes and trees. Cuscuta reflexa spread from one host to another, and on special branching organs called houstoria ${ }^{14}$.

\section{BOTANICAL DESCRIPTION}

Cuscuta reflexais parasitic climber slender stem and branches ${ }^{15}$.Stems very long, rather stout, closely twining, branched, glabrous, pale greenish yellow, sometimes dotted with red. Flowers solitary or in umbellate clusters of 2-4 or in short racemes; pedicels short, glabrous, usually curved (rarely 0), bracts $1.5 \mathrm{~mm}$. long, ovate-oblong, obtuse fleshy. Calyx divided almost to the base, lobes $3 \mathrm{~mm}$. long, slightly unequal, broadly ovate, obtuse, glabrous and fleshy. Corolla white; tube $6-8$ by 4 $\mathrm{mm}$., almost cylindrical; lobes $2.5-3 \mathrm{~mm}$. long, deltoid, acute, reflexed; scales almost at the base of the corolla - tube, large, oblong, subquadrate or somewhat obovate, fimbriate and incurved at the apex. Stamens in the throat of the corolla- tube; filaments scarcely any; anthers about $1 / 2$-exserted beyond the top of the corolla-tube. Ovary ovoid; style simple, very short and thick; stigmas 2, distinct, large thick and fleshy, $1.5 \mathrm{~mm}$. long, ovoid. Capsules 6-8 mm. diam., depressed-globose, glabrous, circumscissilenear the base. Seeds 2-4, large, black, glabrous ${ }^{16}$.

\section{ETHNOMEDICINAL USES OF CUSCUTA REFLEXA}

The rural people of Chhattisgarh use its juice in jaundice by mixing it with milk ${ }^{17}$.Its paste is used in the treatment of Gout $^{18}$.The juice of plant mixed with the juice of Saccharum officinarum is used in the treatment of jaundice ${ }^{19}$.The stem is used in the treatment of bilious disorder, internally in treating protracted fevers and externally in the treatment of body pain and itchy skin. Stems of Cuscuta reflexa is also used in constipation, flatulence, liver complaints and bilious affections. Cuscuta reflexa is also applied as a hair growth promotor ${ }^{20}$. Seeds are said to be tonic, diaphoretic and demulcent and are used to purify the blood. The cold infusion of seeds is given as a depurative and carminatives in pain and stomach ache ${ }^{21}$.

\section{CHEMICAL CONSTITUENTS}

Cuscutin, quercetin, amarbelin, amino acids, cuscutaline, scoparone, melanettin, hyperoside, aromadendrin, taxifolin, astragalin, myricetin, kaempferol, apigenin 7-O- glucoside, luteolin, quercetin, 6,7 - dimethoxy $-2 \mathrm{H}-1$ benzopyran -2-one, 3-(3,4- dihydroxyphenyl) -2- propen- 1- ethanoate, 6,7,8trimethoxy- 2H- benzopyran- 2- one, 3- $(4-\mathrm{O}-\beta-\mathrm{D}-$ glucopyranoside- 3,5- dimethoxyphenyl)- 2- propen- 1 -ol $\beta$ sitosterol, $\alpha$ - amyrin, $\beta$ - amyrin, $\beta$ - amyrin acetate, $\alpha$ - amyrin acetate, oleanolic acetate, oleanolic acetate, oleanolic acid, lupeol, 3 $\beta$ - hydroxyolean- 12(13)- enetridecanoate and heptadecanoate, coumarin, 3,4-O- dicaffeoylquinic acid, 3Ocaffeoylquinic acid, D- mannitol,myricetin 3- O- $\alpha$ rhamnoside ${ }^{22}$.Dulcitol, laurotetanine (alkaloid) it creates convulsion, if used in a large quantity then cause death ${ }^{23}$.Dulcitol, sitosterol, carotenoids, flavonoids ${ }^{24}$, violaxanthin, lutein, lycopene, carotene, $\alpha$-cryptoxanthin ${ }^{25}$ Choline kinase ${ }^{26}$,benzofuran 2, 3, dihydro- , 2-methoxy-4vinylphenol and 2-propenoic acid, 3-(4-hydroxyphenyl)-methyl ester $^{27}$.

The main active principles presented in the plant are cuscutalin $(1 \%)$ and cuscutin $(0.02 \%)$. The plant also contains wax and reducing sugars. The seeds contain amarvelin, resins, oil (3\%) and reducing sugars. These constituents are reported to vary with the host on which the dodder parasitizes. On Santalum album, it yields D-mannitol, while on Glycomis triphylla leutolin or kaempferol, and dulcitol on others. An important cell 
wall degrading enzyme, pectin methyl esterase in A and B forms have been isolated from the filaments containing haustorium ${ }^{28}$.

\section{PHARMACOLOGICAL ACTIVITIES}

\section{Effect on Cardiovascular system}

In a series of experiments, alcoholic extracts of his plant caused a fall in blood pressure on dog. This action was not blocked by atropine, merpyramine or propranolol, thus it could not be exerted through cholinergic, histaminergic or adrenergic mechanism ${ }^{27}$. An ethanolic extract of the stem of Cuscuta reflexa caused a dose-dependent decrease in arterial blood pressure and heart rate in pentothal-anaesthetized rats, and this effect was not blocked by atropine. Hypotensive and bradycardiac effects of Cuscuta reflex were found to be independent of cholinergic receptor stimulation or adrenergic blockage $^{30}$.

\section{Antidiabetic effect}

The methanol and aqueous extracts (200 and $400 \mathrm{mg} / \mathrm{kg}$ body wt) showed significant reduction in blood glucose during OGTT in diabetes rats at $3 \mathrm{~h}$. The treatment also resulted an improvement in body weights, decreased Hb1c and restored lipid profile. Methanolic extracts of Cuscuta reflexa has significant antidiabetic effects and improves metabolic alterations $^{31}$.

\section{Antioxidant activity}

In vitro antioxidant activity of Cuscuta reflexa stem extract by estimating degree of non-enzymatic haemoglobin glycosylation was measured calorimetrically at $440 \mathrm{~nm}$. Ethyl acetate fraction of ethanolic extract showed higher activity than other fractions ${ }^{32}$. Synthesized phytochelatins and carried out modulation of antioxidants in response to cadmium stress in Cuscuta reflexa. The effects of cadmium on growth, the antioxidative enzymes namely catalase peroxidase glutathione reductase, glutathione and phytochelatins were found in callus and seedling of Cuscuta reflexa ${ }^{33}$

\section{Antipyretic activity}

At the dose of $400 \mathrm{mg} / \mathrm{kg}$ body weight the aqueous and ethanol extract reduced $79 \%$ and $83.8 \%$ respectively of the elevated rectal temperature as compared to reference drug Paracetamol $(96.5 \%)$ after 6 hours of treatment. It appears that the antipyretic activity of Cuscuta reflexa may be due to inhibition of prostaglandin synthesis. Again the extracts contain flavonoids and saponins, the antipyretic potential of which has been reported ${ }^{34}$.

\section{Spasmolytic action}

Aqueous and alcoholic extracts of Cuscuta reflexa stem have got a relaxant and spasmolytic action on small intestine of guinea pig and rabbit. Also, the extracts exhibited acetyl choline-like action $^{35}$.

\section{Anti-HIV activity}

The crude water extracts of Cuscuta reflexa exhibited anti- HIV activity that could be due to combinatory effects with compounds of different modes of acion ${ }^{36}$.

\section{Antitumor activity}

Administration of Aqueous and ethanol extracts of Cuscuta reflexa whole plant at doses of 200 and $400 \mathrm{mg} / \mathrm{kg}$ body weight resulted in a significant $(\mathrm{p}<0.05)$ decrease in tumor volume and viable cell count but increased non-viable cell count and mean survival time, thereby increasing the life span of the tumorbearing mice. Restoration of hematological parameters - RBC, $\mathrm{Hb}, \mathrm{WBC}$, and lymphocyte count to normal levels in extract treated mice was also observed ${ }^{37}$.

\section{Anti-arthritic and nephroprotective effect}

Antiarthritic activity of Aqueous and Methanol extracts of Cuscuta reflexa was evaluated in vivo using formaldehyde and turpentine oil-induced arthritis models and in vitro using formaldehyde and turpentine oil-induced arthritis models and in vitro using protein denaturation methods. AMECR at $600 \mathrm{mg} / \mathrm{kg}$ significantly reduced paw edema and joint swelling with maximum inhibition of $71.22 \%$ at the $6^{\text {th }}$ hour for turpentine oil and $76.74 \%$ on the $10^{\text {th }}$ day for formaldehyde. Likewise in vitro results corroborate significant concentration dependent increase in $\%$ protection at $800 \mu \mathrm{g} / \mathrm{mL}$ against both bovine serum albumin $(89.30 \%)$ and egg albumin $(93.51 \%)$ denaturation. This result shows that AMECR provides protection against arthritis and nephrotoxicity that might be due to the existence of phytoconstituents ${ }^{38}$.

\section{Anti-inflammatory activity}

Alcoholic and aqueous extract of stem of Cuscuta reflexa were evaluated for their anti-inflammatory activity in carrageenan induced paw edema model in rats, and compared to the activity of the standard drug, Ibuprofen. These extracts were given orally at a concentration of 100,200 and $400 \mathrm{mg} / \mathrm{kg}$ bd. Wt. before carrageenan injection. Both the extracts with medium and higher doses i.e. $200 \mathrm{mg} / \mathrm{kg}$ and $400 \mathrm{mg} / \mathrm{kg}$ have reduced edema volume by $47.27 \%, 72.72 \%$ and $57.72 \%, 80.00 \%$ respectively at $5^{\text {th }} \mathrm{h}$ as compared to standard drug Ibuprofen $96.36 \%$. Thus this study revealed that the selected extracts of Cuscuta reflexa exhibited a significant anti-inflammatory activity in carrageenan induced paw oedema model in rats ${ }^{39}$.

\section{Antimicrobial activity}

Ethanolic whole plant extracts obtained from Cuscuta reflexa were screened against Gram positive (Bacillus subtilis and Staphylococcus aureus) and Gram negative (Escherichia coli and Salmonella typhi) bacteria to evaluate their antimicrobial activity. Of the four concentrations of plant extract tested (200 $\mu \mathrm{g} / \mathrm{mL}, 300 \mu \mathrm{g} / \mathrm{mL}, 400 \mu \mathrm{g} / \mathrm{mL}$ or $500 \mu \mathrm{g} / \mathrm{mL}), 500 \mu \mathrm{g} / \mathrm{mL}$ elicited the greatest zones of bacterial inhibition across three of the bacteria. In contrast, the growth of Salmonella typhi was not halted regardless of extract concentration. Overall, although the greatest antimicrobial activity was demonstrated to be against $\mathrm{E}$. coli at a concentration of $500 \mu \mathrm{g} / \mathrm{mL} \quad(24.6 \pm 0.24)$, upon comparison to the other bacteria, both $\mathrm{B}$. cereus and $\mathrm{S}$. aureus reduced similar zones of inhibition upon comparison to their positive antibiotic control the ethanolic extract of Cuscuta reflexa contains a myriad of compounds such as alkaloids, carbohydrates, glycosides, flavonoids, tannins, phenolic compounds and steroids. The authors determined that it is the flavonoid, glycosides contained within the plant which are responsible for the inherent antimicrobial activity. This preliminary investigation suggests that the ethanolic extracts from Cuscuta reflexa do possess significant antimicrobial properties $^{40}$. 


\section{Hair growth activity}

The petroleum ether and ethanolic extract of Cuscuta reflexa were given at the dose $250 \mathrm{mg} / \mathrm{kg}$ in male swiss albino rats. Cyclophosphamide $(125 \mathrm{mg} / \mathrm{kg})$ was used to induce alopecia. This study was shown to be capable of promoting follicular proliferation or preventing hair loss in cyclophosphamideinduced hair fall ${ }^{41}$.

\section{FORMULATION}

Akashvalli arka ${ }^{42}$

\section{DISCUSSION}

This review article reveals that Cuscuta reflexa is a very important medicinal plant. It is Called miracle plant in ethnobotany. Cuscuta reflexa is a parasitic plant belong to the Convolvulaceae family. Its depend upon host plant for nutrients, water \& carbohydrates. Cuscuta lacks roots or leaves but possesses specific penetrating organs, called haustorium. It causes huge loss to the crop plants every year. Still Cuscuta reflexa have some medicinal properties including antispasmodic, antidiabetic, antimicrobial, antiviral, antihypertensive, muscle relaxant, antioxidant, hair growth promoting activity, antipyretic and antitumor. As evident by a number of studies cited above. Different parts are used to treat different diseases and have important place in the Ayurveda. The plant needs to be explored more so that more formulations can be proposed and used practically for treatment of diseases.

\section{REFERENCES}

1. Sermakkani M, Thangapandian V. GC-MS analysis of Cassia italic leaf methanol extract. Asian $\mathrm{J}$ of Pharm and clinical Res 2012;5(2):90-94.

2. Dawson JH, Musselman LJ, Wolswinkel P, Dorr I.Biology and control of Cuscuta. Rev Weed Sci 1994;6:265-317.

3. Kirtikar K and Basu BD. Indian Medicinal Plants, Vol. III. Periodic Expert Book Agency. 1981;1741-1742.

4. Kaur A. Cuscuta reflexa Roxb. A parasitic plant in Ayurved. Int J of Pharm Res and Bio-Sci 2013;2(2):180-190.

5. Kumar A, Rani S, Sagwal S. Recent review on Plant Molecular Biology. Phytophysiology, Phytochemistry and Ethnopharmacology of Cuscuta reflexa Roxb. A wonderful Parasitic Plant. Int Res J of Pharmacy 2012;3:30-38.

6. Chunekar KC. Bhava Prakash Nighantu. Varanasi: Chaukhambha Bharati Academy;2004. p.447-448.

7. Tripathi I. Raj Nighantu. Varanasi: Chaukhambha Krishna Academy; 2006. p.38-39.

8. Bapalal G. Nighantu Adarsh Vol.II. Varanasi: Chaukhambha Bharti Academy; 2005. p. 97-99.

9. Gauod SD. Shankar Nighantu. Varanasi: Chaukhambha Vidhyabhavan; 2002. p. 11.

10. Shukla SD. Madanpal Nighantu. Lucknow: Tejkumar Press; 1952. p. 28.

11. Vijikumar S. Cuscuta reflexa Roxb. - A wonderful Miracle Plant in Ethnomedicine. Indian $\mathbf{J}$ of Natural Sci 2011;11:677.

12. Nandkarni KM. Indian Materia Medica Vol.I Bombay:Popular Prakashan Pvt Ltd; 1976. p.419-420.

13. Nandkarni KM. The Indian Materia Medica. Vol-I. Mumbai: Bombay popular prakashan; 2005; 419-420.

14. Kirtikar KR, Basu BD. Indian medicinal plants Vol.III. Dehradun: Bishenmahendra pal singh;2001. p. 1741.

15. Sastry JLN. Dravyagua Vijnana. Vol.II. Varanasi; Chaukhambha Orientalia: 2005. p. 863-864.
16. Kirtikar KR \&Basu BD. Indian Medicinal Plants,Vol. III, Delhi: Periodical Expert Book Agency; 1981. p. 1741-1742.

17. CGMFPFED. Traditional Medicine system of Chhattisgarh. Raipur: Chhattisgarh Samvaad;2015. p. 105.

18. CGMFPFED. Traditional Medicine system of Chhattisgarh. Raipur: Chhattisgarh Samvaad; 2015.p. 208.

19. Kirtikar KR, Basu BD. Indian medicinal plants. Vol III. Delhi:Periodical Expert Book Agency; 1984. p. 1740.

20. Pandit S, Chauhan NS, Dixit VK. Effect of Cuscuta reflexaRoxb on androgen induced alopecia. $\mathrm{J}$ of Cosmet Dermatol 2008;7(3):199-204.

21. Chopra RN Nayer SL, Chopra IC. Glossary of Indian medicinal plants. New Delhi: Council of Scientific and Industrial Research; 1956.

22. Gupta AK, Tandon N, Sharma M. Quality Standards of Indian Medicinal plants. Vol-V. New Delhi: Medicinal Plants Unit Indian Council of Medical Research; 2008. p. 185-192.

23. Sharma PV. Dravya-gunaVijnana. Vol.II. Varanasi: Chaukhambha Bharti Academy; 2006. p. 487-88.

24. Subramanian SS, Nair AGR. Chemical components of C.reflexa. Indian J Chem 1963; 1:501.

25. Mukherjee R, Bordoloi J, Goswami A, Goswami BC. Carotenoids of dodder grown on hedge, Clerodendrum enermy. Adv Nat Appl Sci 2008;2(3):99-102.

26. Setty PN, Krishnana PS. Choline kinase in C.reflexa. Biochem J 1972;126(2):313-324.

27. BaisN, Kakkar A. Phytochemical Analysis of Methanolic Extract of Cuscuta reflexa Grown on cassia fistula and Ficus benghalensis. Int J of Pharm Sci 2014;25(2): 33-36

28. The wealth of India Vol.II. New Delhi: NISCAIR-CSIR; 2004.p. 296-297.

29. Singh GS, Garg KN. Some pharmacological studies on C.reflexa plant. Indian J. pharmacol 1973;5(2):344-345.

30. Gilani AUH, Aftab K. pharmacological actions of Cuscuta reflexa. Int J pharmacogn.1992;30(4):296-302.

31. Rath D, Kar DM, Panigrahi SK. Antidiabetic effects of C.reflexain streptozotocin induced diabetic rats. $\mathrm{J}$ of Ethnapharm192;2016:442-449.

32. Yadav SB, Tripathi V, Singh RK, Pandey HP. Antioxidant activity of C.reflexa stems. Indian J Pharm Sci 2000;62(6): 477-478. Srivastav S, Tripathi RD, Dwivedi UN. Synthesis of phytochelatins and modulation of antioxidants in response to cadmium stress in C.reflexa. J plant physiol 2004;161(6):665-674.

33. Bhattacharya S, Roy B. Preliminary investigation on antipyretic activity of C.reflexain rats. J Adv Pharm Technol Res 2010 Jan-March;1(1):83-87.

34. Prasad DN. Preliminary pharmacological investigations on C.reflexa. Indian J Med Res. 1965;53:465-470.

35. Mahmood N, Piacente S, Bruke A, Khan A, Pizza C. Constituents of C.reflexa are anti-HIV agents. AntivirChem Chemother1997;8(1):70-74.

36. Chatterjee D, Sahu RK, Jha AK, Dwivedi.Tropical J Pharm Research August 2011;10(4):447-454.

37. Alamgeer, Niazi SG, Uttra AM, Qaisesr MN, Ahsan H. Appraisal of anti-arthritic and nephroprotective potential of Cuscuta reflexa, Pharm Biology. 2017;55(1):792-798.

38. Katiyar NS, Singh AP, Gangwar AK and Rao NV. Evaluation of carrageenan induced antiinflammatory activity of stem extracts of Cuscuta reflexa (roxb) in rats. Int $\mathrm{J}$ of Res in Pharm and Chem 2015;5(2):322-326.

39. Manirujjaman, Suchana S, Collet T, Nawshin LN, Chowdhury MAR. Antimicrobial Effects of Ethanolic Extracts from Cuscuta reflexa. Int $\mathrm{J}$ of Pharmacognosy and Phytochem Res 2016; 8(6):930-932.

40. Patel S, Sharma V, Chauhan NS, Dixit VK. A study on the extracts of Cuscuta reflexa Roxb. In treatment of 
cyclophosphamide induced alopecia. DARU J of Pharm Sciences2014;22:7.

41. Tripathi I. Arkaprakash of Lankapati Ravan. Varanasi: Krishna Das Academy 1995;53.

\section{Cite this article as:}

Lalchand et al. Cuscuta reflexa (dodder plant): A critical review of the medicinal plant used in Ayurveda. Int. J. Res. Ayurveda Pharm. 2017;8(6):38-42 http://dx.doi.org/10.7897/22774343.086288

\section{Source of support: Nil, Conflict of interest: None Declared}

Disclaimer: IJRAP is solely owned by Moksha Publishing House - A non-profit publishing house, dedicated to publish quality research, while every effort has been taken to verify the accuracy of the content published in our Journal. IJRAP cannot accept any responsibility or liability for the site content and articles published. The views expressed in articles by our contributing authors are not necessarily those of IJRAP editor or editorial board members. 